SACRAMENTAL POETICS AT THE DAWN OF SECULARISM 

Cultural Memory

in the

Present

Mieke Bal and Hent de Vries, Editors 



\section{SACRAMENTAL POETICS}

\section{AT THE DAWN OF SECULARISM}

When God Left the World

Regina Mara Schwartz 
Stanford University Press

Stanford, California

2008 by the Board of Trustees of the Leland Stanford Junior University. All rights reserved.

No part of this book may be reproduced or transmitted in any form or by any means, electronic or mechanical, including photocopying and recording, or in any information storage or retrieval system without the prior written permission of Stanford University Press.

Library of Congress Cataloging-in-Publication Data

Schwartz, Regina M.

Sacramental poetics at the dawn of secularism : when God left the world / Regina Mara Schwartz.

p. cm. - (Cultural memory in the present)

Includes bibliographical references and index.

ISBN 978-0-8047-5667-9 (cloth: alk. paper)—ISBN 978-0-8047-5833-8 (pbk. : alk. paper) I. English poetry-Early modern, I500-1700-History and criticism. 2. Christian poetry, English-Early modern, I500-1700-History and criticism. 3. Christianity and literature-England-History-17th century. 4. Rites and ceremonies in literature. 5. Aesthetics, Modern-17th century. 6. God in literature. 7. Ritual in literature. I. Title.

$\mathrm{PR}_{545 \cdot \mathrm{R}_{4} \cdot \mathrm{S}_{39} 2008}$ $820.9^{\prime} 3823$ 2007037710

Typeset by Westchester Book Group in II/13.5 Adobe Garamond

This book was published with the assistance of Northwestern University. 
In the Christian tradition, an initial privation of body goes on producing institutions and discourses that are the effects of and substitutes for that absence: multiple ecclesiastical bodies, doctrinal bodies, and so on. How can a body be made from the word? This question raises the other haunting question of an impossible mourning: "Where art thou?" These questions stir the mystics.

-Michel de Certeau, The Mystic Fable 
